\title{
THE INFLUENCE OF DISCONTINUITY FABRIC AND OTHER FACTORS ON OPTIMUM EXPLOITATION OF DIMENSION STONE
}

\author{
Ivan TOMAS̆IĆ \\ Faculty of Mining, Geology and Petroleum Engineering of Zagreb University, Pierottijeva 6, 41000 Zagreb, Croatia
}

Key-words: Dimension stone, Deposits, Discontinuity fabric, Exploitation, Optimalization, Utilization

Dimension stone as a specific nonmetallic raw material, regarding deposit conditions, exploitation methods and processing, demands an adequate estimate of dimensioning i.e. optimalization of the exploitation in relation to the structural elements.

The analyzed and presented examples show that in natural conditions adaptation of the exploitation technology to the discontinuity fabric could result in considerable gains in utilization of rock mass in stone blocks, specialy if these blocks are cases of highly decorative stone with good physical and mechanical properties.

The calculated and presented diagrams fit well into world analysis trends concerning exploitation and processing of dimension stone. Thisi is confirmed by the improvement of technology for smaller stone blocks can be exploited and processed profitably.

\section{Introduction}

In the past decade several important factors have had an essential influence on the development of exploitation and production of dimension stone. These factors have greatly effected the number of active quarries, the size of commercial blocks and the number of stone varietes.

Some of the most important are the economic factors which are very dependant on the existing production and market relations. They are connected with production and are influenced mainly by exploitation and processing technologies. They are also dependant on stone decorativety, its technical properties and the geological characteristics of the deposit and specially the elements of its discontinuity fabric.

Traditionally the evaluation of the stone on the market, in buildings and deposits is made according to the decorative, the technical and the geological criterions.

The influence of the mentioned criterions was particularly great on the quantity of active quarries and thereby on the number of variety of stones. The number of quarries together with the number of variety of stones increased in Croatia. Since after 1964. due to economic crisis their number declined rapidly. Growth was again registered in the period between 1973. and 1981. followed by a decline till 1987. Today the number of producing
Ključne riječi: Arhitektonski kamen, Ležišta, Strukturni sklop, Eksploatacija, Optimiranje, Iskoristivost

Arhitektonski kamen kao specifična nemetalna mineralna sirovina, s obzirom na svojstva ležišta, način eksploatacije i prerade, zahtjeva odgovarajuću prosudbu kojom se mora izvršiti dimenzioniranje odnosno optimalizacija eksplotacijskih u odnosu na strukturne elemente.

Analizirani i prikazani primjeri pokazuju da bi se u realnim uvjetim prilagodbom tehnologije eksploatacije strukturnom sklopu mogli postići znatni efekti u iskoristivosti stijenske mase u blokovima posebice ako se radi o visoko dekoratinom kamenu dobrih fizičko-mehaničkih svojstava.

Analizom utvrđeni i prikazani dijagrami uklapaju se u svjetska kretanja u eksploataciji i preradi arhitektonskog kamena. To potvrđuje usavršavanje tehnologija kojima se manji blokovi i tomboloni mogu rentabilno eksploatirati i preradivati.

quarries is growing again. The interest for reactivation of abandoned quarries and opening of new ones is growing also, due to the privatisation and legal provisions which allow quarrying leases to be obtained in a short time.

Exploitation was abandoned in quarries that generally produced small blocks which were usually a consequence of an unfavorable rock-mass discontinuity fabric in the deposit and the application of unsuitable exploitation technologies.

The main elements that characterize our trade market are distinct. The market reacts favourably to decorativity of the stones and their technical properties (the physical and mechanical properties and resistance to the activity of various exogeneous influences). The customers accepted almost all the supply of stone on the market including stone of poorer quality. Thus the market as a factor had no significant influence on the number of operating quarries and the number of commercial variety of stones. The existance of numerous variety of stones which are not produced anymore although they had high decorative and good physical and mechanical properties proves this. The trade market did not have an significant influence on the final product as it did on the stone blocks. The demand for large blocks was governed by the existing processing technologies.

The main reasons for the decline in number of variety of stones and quarries thus should be fo- 
und in the capability of organizing economical exploitation and block processing in unfavourable economic periods, and unfavourable deposit conditions such as those with peculiar chracteristics of the discontinuity fabric which often demand maximal adaptability.

Studies (Tomašić, 1978 and 1982) imply a dependance between the utilization level of a dimension stone deposit, discontinuity fabric and the exploitation technologies applied.

The utilization level of rock mass during quarrying of healthy rock bloks in a deposit is one of the main indicators of economical grade and justifiability of financial investments.

Stone block processing in regard to the block size for years depended on the level of technology used. Processing of small stone blocks has only been utilized in the past ten years. Posibilities for future development of stone industries should lay in this direction.

Industrializatin and automatization in processing of smaller blocks will considerably contribute to the increase in number of quarries and in the number of variety of stones on the market.

\section{The deposit discontinuity fabric and exploitation technology}

Experience implies a major influence of decorativity, technical properties of stones together with geological structural characteristics in making an estimate of dimension stone during the selection of optimal parameters for opening and elaboration of new and abandoned deposits.

The importance of the decorative, technical and geological criterion is stressed by Bilbija et. al. (1974); Tomašić and Crnković (1974); Toma šić (1976a, 1976b) and also by Crnković and Bilbija (1984). analyzed. One example (Tomašić, 1982) is displayed in fig. 1., and also with corresponding curves, in two more examples in figs. 2 and 3. To obtain a convenient picture concerning the utilization level of rock mass in dependency with the discontinuity fabric and the applied exploitation technology the whole problem is simplified and analyzed as a two-dimensional problem. In order to elaborate the example of the calculation of the surface utilization coefficient of rock mass was applied on perpendicular profiles along the working bench with a total surface of $36 \mathrm{~m}^{2}$. It is mainly based on elements of certain structural characteristics, namely the discontinuity positions (the intersection angle lies betwen $80-82^{\circ}$ and they close an angle of $44^{\circ}$ and $56^{\circ}$ relative to the horizon), obtained during the exploration of the dolomite marble deposit Sivec near Prilep (fig. 1). The figure displays only two of numerous examples of intersections with diferent densities of discontinuities. The results obtained by analysis of these examples are presented graphically on figs. 2 and 3 , showing adequate curves corresponding to two different exploitation methods applied depending on the density and utilization of rock mass.

The curves in fig. 2, obtained on the basis of examples similar to the one in fig. 1a, display the possibility of utilization of stone blocks of constant surface size $(1.4 \mathrm{~m} \times 1.4 \mathrm{~m})$. The curves in fig. 3, which result from an example similar to that displayed in fig. $1 \mathrm{~b}$, demonstrate the wast potentiality of utilization enhancement under the condition that in the deposit, or as in this case in the model, blocks with different surface sizes (for exp. $1.4 \mathrm{~m} \times 1.4 \mathrm{~m} ; 1.2 \mathrm{~m} \times 1.2 \mathrm{~m}$ and $1.0 \mathrm{~m} \times$ $1.0 \mathrm{~m})$ are exploited. The first exploitation method involves the cutting of perpedicular cuts every $1.4 \mathrm{~m}$. The second exploitation method consits
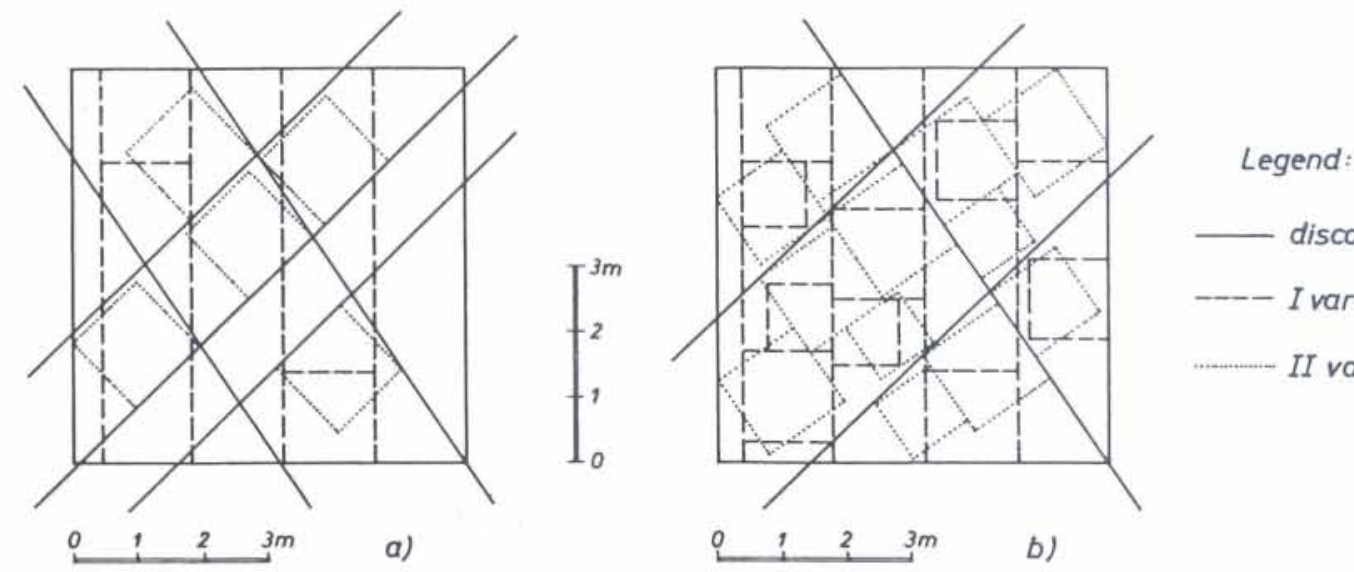

- discontinuity

-- I variant of exploitation

........... II variant of exploitation

Fig. 1. Vertical intersections through the working bank (36 $\mathrm{m}^{2}$ ) with surfaces of blocks; a) $1.4 \mathrm{~m} \times 1.4 \mathrm{~m}$, b) $1.4 \mathrm{~m}$ $\times 1.4 \mathrm{~m} ; 1.2 \mathrm{~m} \times 1.2 \mathrm{~m}$ and $1.0 \times 1.0 \mathrm{~m}$.

Much attention must be dedicated to analysis and forecast of the utilization level of rock masses. This mostly depends on the density and mutual spatial dependance of natural discontinuities. This problem has been frequently studied and of stone detachment by means of pneumatic perforators in combination with wire-saws, but only under the condition that during stone block exploitation the adjustment to fissures and fissure systems, that are the discontinuities what ever their origin and position is taken in account. 


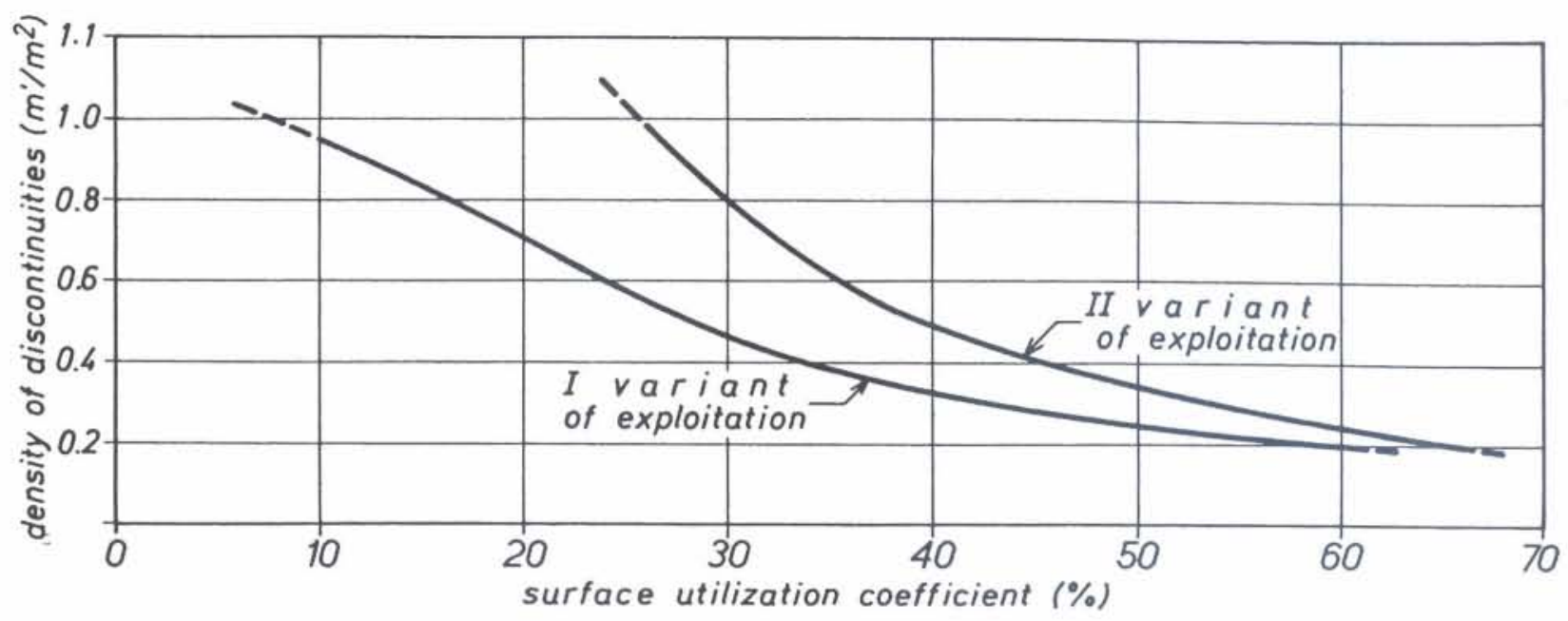

Fig. 2. First example: Diagram of discontinuity density versus surface utilization coefficients (surfaces of stone blocks $1.4 \mathrm{~m} \times 1.4 \mathrm{~m}$ )

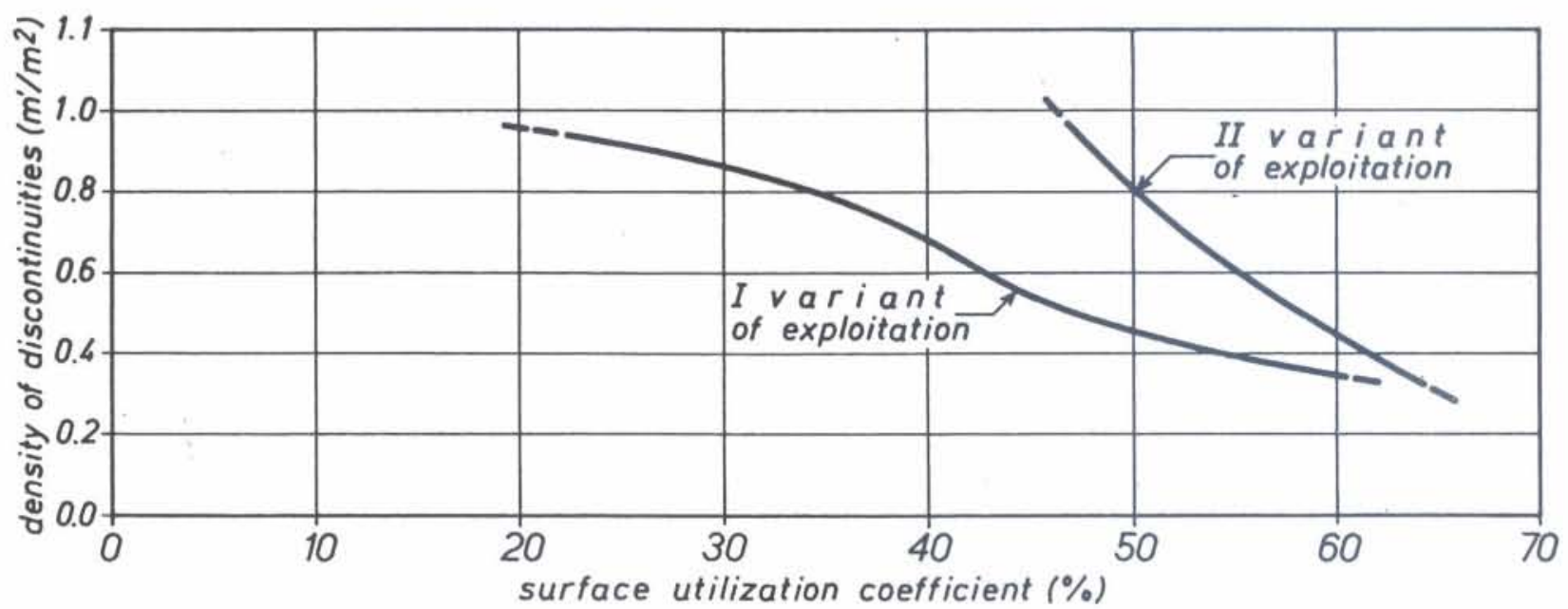

Fig. 3. Second example: Diagram of discontinuity density versus surface utilization coefficients (surfaces of stone blocks $1.4 \mathrm{~m} \times 1.4 \mathrm{~m} ; 1.2 \mathrm{~m} \times 1.2 \mathrm{~m} ; 1.0 \mathrm{~m} \times 1.0 \mathrm{~m})$

If this problem is set as by Brown (1971), it can be treated as an optimalization problem in some industry branches as for exp. paper, sheet, metal, textile, etc.

Also according to Erdös and Graham (1975) the solution of this problem would be similar to the solution of the problem of placing "n $"$ equal squares into larger squares of minimal surface.

The analyzed examples are used to solve problems encountered in strongly fractured rock masses. The evaluation of such masses is difficult and complicated.

The question arises how from the analyzed examples in figs. 2 and 3 to extricate the basic elements useful for optimalization, in regard to the size of the stone-blocks, and to chose the necessary technology for exploitation and processing.

The values on the ordinate represent the value of fissure density in $\mathrm{m}^{1} / \mathrm{m}^{2}$. For example the density of $1 \mathrm{~m}^{1} / \mathrm{m}^{2}$ means that in a certain part of a deposit the distance between fissures is $1 \mathrm{~m}$. The density of $0.4 \mathrm{~m}^{1} / \mathrm{m}^{2}$ implies (in an ideal case) a distance of $2.5 \mathrm{~m}$ between fissures (a les fractured rock mass). It must also be taken into account that the fissure systems close an angle of $44^{\circ}$ and $56^{\circ}$ with the horizon (fig. 1). It would be convenient for both exploitation methods if these were vertical. The values of surface utilization coefficients in percentages are placed on the abscissa.

The graphical displays, the examples in figs. 2 and 3 ,imply a series of important conclusions. In figure 2 an obvious difference is clearly noticeable in the utilitization of the first (I) and second (II) variant of exploitation technology.

With the increase of fracturing, the density values and also the utilization of the first and second exploitation methods decrease. A difference is present and it is quite large in the sphere of our study, in the zone with density of $1 \mathrm{~m}^{1 / \mathrm{m}^{2}}$. This is the area where there still is significant difference in utilization in favour of the second exploitation method. Consequently in strongly fractured deposits there is a boundary limit where it is profitable to apply the second exploitation method. The po- 
sition of this boundary namely, depends also on other factors previously mentioned (physical and decorative properties), and it can be positioned on the basis of experience or a corresponding economic technical analysis.

Particularly large differences must be stressed in utilization achived during exploitation of bloc$\mathrm{ks}$ of various dimensions as a consequence of adaption to fissure systems and their density. This is best observed in the analysis of the second example (fig. 3 ) in comparison to the first example (fig. 2). These differences can also be expressed numerically. From the figures a large increase in utilization can be observed for both exploitation methods. Thus, for fissure density of 0.9 $\mathrm{m}^{1} / \mathrm{m}^{2}$, from diagrams in figs. 2 and 3 , the increase for the first exploitation method amounts to about $120 \%$, while the surface utilization coefficient amounts $25.5 \%$. For the second exploitation method the increase can amount to $79 \%$ and the corresponding surface utilization coefficient is equal to $48.1 \%$.

In the second example (fig. 3 ) the difference between the two exploitation method, with fissure density of $0.9 \mathrm{~m}^{1} / \mathrm{m}^{2}$ is about $20 \%$. With the fissure density of $0.4 \mathrm{~m}^{1} / \mathrm{m}^{2}$, calculated from the diagrams in figs. 2 and 3, the increase for the first exploitation method amounts $59 \%$ and for the second $34 \%$. Therefore, less fractured rock masses, cause lower increase, meaning that the applied exploitation technology has lesser influence on utilization.

In the second example (fig. 3 ) the difference between the surface utilization coefficients of the two exploitation methods for fissure density of 0.4 $\mathrm{m}^{1} / \mathrm{m}^{2}$ is $7.2 \%$.

The introduction of the second exploitation method which demands maximal adaption to the fissure system, i. e. detachment of stone block by taking in account the position of natural discontinuity planes with the help of pneumatic block-cutters in combination with hidraulic wedges and cylinders, air pillows, helicoidal wire, and mobile and adaptable diamond wire saws, would increase the utilization results in more fractured parts of the rock mass.

Such an approach would increase the interest for deposits in which stone decorative and technical properties satisfy, but which have less favourable geological conditions, specially concerning their structural fabric, and where common exploitation technologies achive low utilization coefficients.

There are also other methods that can considerably influence the utilization increase. Block detachment by gunpowder in strongly fractured rock masses is proposed by Krebel (1974). The consequence of application of this method is that there is minimal damage to the healthy rock mass during separation. After rolling or tumbling of the stone mass which usually decomposes along discontinuity planes, the dressing of block to various dimensionsis performed. The increase of utilization in this method is equal to that achived in the previously described elements of the second exploitation method.

Recently Cotman and Damjanić (1992) described the great efficiency and favourable effect achived by application of combined methods and technologies. They stress the possibility of separation of huge blocks from healthy rock masses. Their method with minor modifications could be also applied to more fractured rock masses. The adventages of their method as implied by the authors are justified by high productivity, lower exploitation expenses and higher rock mass utilization.

Where to actually place the optimal boundary between the described exploitation method depends on the particular conditions of each individual deposit. It can be determined only by calculation and comparison of actual expenses of various exploitation methods.

The analyzed and presented examples imply an important influence of the discontinuity fabric on the choice of optimal exploitation conditions and stone block processing. Therefore, design and dimensioning of quarries, together with discontinuity fabric analysis must also take into account the correct choice of method and exploitation technology.

Problems of dimensionig and optimalization in quarries are discused by Milocco (1988). The most important factors presumed by him are the determination of quarry size, number of workers, reserves of dimension stone, varieties of stone and their market values, investment rates and bank confidence. The author explains that productivity and the making of profit are not so dependant on the dimensions of the quarry but on the utilitization program for equipment and tools available. The number of employees is emphasized through the importance of individual perfomance. Determination of the production rate is stressed as very important and he emphasizes that it is not the same if intesive quarrying of a small deposit is planned or if one plans moderate quarrying of a larger deposit. Annual production must be in proportion with available reserves and deposit conditions demand and price on the market are also emphasized, together with the importance of market and deposit perspective through short and long-term financial support of banks.

Structurally complex, but perspective smaller deposits, studied in this article, dimensioning and optimazing of the size of the deposit, the necessary technology and number of employees, demand maximal adaptance to the mentioned conditions.

\section{Conclusion}

The presented examples of utilization analysis are based on the results of planar i.e. two-dimensional model analysis.

The analyzed examples imply a possibility of considerable utilization enhancment of block surfaces with the application of the second (II) exploitation method (along discontinuity planes), vi- 
sible specially in the example in fig. 3 (various dimensions i.e. surfaces are exploited).

The analyzed and presented examples show that in natural conditions adaption of the exploitation technology to the discontinuity fabric could atain considerable gains in utilization of rock mass in stone blocks, specially if these blocks are about $1 \mathrm{~m}^{3}$. Such an approach should be profitable, particularly in cases of highly decorative stone with good physical and mechanical properties.

From the facts presented it is obvious that dimension stone as a specific nonmetallic mineral raw material, in regard to deposit conditions, exploitation method and processing demands an adequate estimate of dimensioning i.e. optimalization of structural elements, what is achived in this study.

The number of elements that must be in optimum proportion is greater in structurally more complex deposits.

The calculated and presented diagrams fit well into world analysis trends in exploitation and processing of dimension stone. This is confirmed by the improvement of technology by which smaller stone blocks can be exploited and processed profitably.

The development level of certain regions and countries significantly influences the openings of new and reopening of old dimension stone deposits. The low price of labour in comparison to west-european countries enables employment of necessary man power and prevailing of the initial very costly period of deposit opening and elaboration. In these regions the opening of new and reopening of an old deposit is more frequent. Neverthereless, decorativity, stone block dimensions, and stone durability in a physical and chemical sense, largely influence the opening of quarries.

At the present time Croatia has a situation that is most favourable for openings of dimension stone deposits. This country lacks domestic variety of stones acceptable for interior paving. These paving varieties must have high density and a permanent lustre. The demand for cheaper stone raw material of higher quality, regardless to block si$\mathrm{ze}$, only proves trends similar to those in the world.

Today in the quarrying practice there are only a few examples that are in concordance with the interpretation presented in this study.
The production of stone slabs of smaller dimensions but from quality stone could completely satisfy a part of the domestic market. The economic situation today is equal to the period before 1965, when a large number of quarries was operating with even a larger variety of dimension stones. With the time as the price of the labour will rise a part of the producing quarries shall close. However, this time, a portion of them will stay in production due to favourable development of exploitation and processing technologies.

\section{Received: 25.I. 1994.}

Accepted: 9.VI. 1994.

\section{REFERENCES}

Bilbija, N., Crnković, B. i Grimšičar, A. (1974): Perspektivna područja za eksploataciju arhitektonsko-građevinskog kamena. Zbornik radova, Simpozij: Ukrasni i tehnički kamen, 1-16, Opatija.

Brown, A.R. (1971): Optimum Packing and Depletion. MacDonald - London and American Elsevier Inc., 107 pp, New York.

Cotman, I. i Damijanić, A. (1992): Nova otkopna metoda u eksploataciji slojevitih ležišta arhitektonskog kamena. Rud.-geol.-naft. zb., 3, 69-76, Zagreb.

Crnković, B. i Bilbija, N. (1984): Vrednovanje arhitektonsko-građevinskog kamena. Geol, vjesnik, 37, 81-95, Zagreb.

Erdös, P. and Graham, R.L. (1975): On Packing Squares with Equal Squares. Journal of Combinatorial Theory 19, $119-123$.

Krebel, K. (1974): Metoda eksploatacije ukrasnog kamena pomoću detonirajućeg štapina i crnog baruta. Zbornik radova, Simpozij: Ukrasni i tehnički kamen, 167-176, Opatija.

Milocco, N.A. (1988): Problemi di dimensioni di cave e miniere. Marmi-graniti-pietre 160,14-28, Milano.

Tomašić, I. i Crnković, B. (1974): Osvrt na postojeći propis o klasifikaciji i kategorizaciji rezervi ukrasnog kamena i vođenju evidencije o njima. Zbornik radova, Simpozij: Ukrasni i tehnički kamen, $17-25$, Opatija.

Tomašić, I. (1976a): Metodologija istraživanja ležišta na primjeru obrađenog ležišta Vinicita u Vinici kraj Varaždina. Simpozij: Sirovinska baza kao osnova za dalji razvoj industrije arhitektonsko-gradevinskog kamena, 28-33, Sarajevo.

Tomašić, I. (1976b): Ocjena cjelovitosti stijenske mase (ležišste arhitektonsko-građevinskog kamena Pećina kraj Vinice). Gradevinar 11, 473-482, Zagreb.

Tomašić, I. (1978): Iskoristivost ležišta arhitektonskog kamena u ovisnosti od tektonskog sklopa i tehnologije eksploatacije. Magistarski rad, Sveučilište u Zagrebu. $63 \mathrm{pp}, \mathrm{Za}$ greb.

Tomašić, I. (1982): Iskoristivost ležišta arhitektonsko-gradevnog kamena u ovisnosti od tektonskog sklopa i tehnologije eksploatacije. Rudarsko-metalurški zbornik 29, $332-342$, Ljubljana. 